\title{
Measurement Of Information Technology Used and Communication of Farmers Group In Sub-district of Jatinangor, Sumedang District
}

\author{
Aldika Karisnoviandi', Roni Kastaman², Irfan Ardiansah² \\ ${ }^{1}$ Alumnae Department of Agricultural Engineering and Biosystem \\ Faculty of Agroindustrial Technology Padjadjaran University \\ ${ }^{2}$ Lecturer at Department of Agroindustrial Technology, \\ Faculty of Agroindustrial Technology Padjadjaran University \\ Email: snaip2011@gmail.com
}

\begin{abstract}
Information and communication technology (ICT) can improve productivity and reduce costs / expenses in the agricultural sector and rural development. Jatinangor is one of sub-district on Sumedang with the highest economic growth, where the agricultural sector ranks third in contributing the economy. The use of ICT for farmers in Jatinangor it was not known the degree to which capable of being applied, then need to know the level of use of ICT by Jatinangor farmers. Method used in this research was descriptive method that described the data to determine size of the ICT usage level. Data is formulated into index numbers of ICT usage level or Information and Communication Technology Usage Level Quotient Index which was obtained by formulating an operational definition of variable using analysis of UNDP index calculation and Location Quotient analysis. The results of the study showed that the measurement of the ICT usage level covering by 4 indicators: farmers characteristic, farmers environment, ICT characteristic, and farmers behavior. Farmers group has the highest of the ICT use in Jatinangor is Harapan I, in Bina Karya Mandiri, Cileles Village with an index of 1,1380, and ICT absorption level of $50 \%$. Farmers group has the lowest of the ICT use is Jeruk Mipis, in Mulya Jaya, Cipacing Village with an index of 0,9156, and ICT absorption level of $36 \%$.
\end{abstract}

Keywords: ICT, Usage Level, Usage Level Quotient, Farmers Group, Jatinangor

\section{INTRODUCTION}

Technological developments are increasing rapidly in Indonesia. The advancing era provides changes in the various life sectors due to technological support. The current technology is associated with information and communication media. The presence of information and communication technology makes it easier for humans to interact and get information, so that all activities faster and easier to do. Information and communication technology (ICT) becomes a very important need for human in the present. The access of ICT in every island in Indonesia has reached an average rate of $92.05 \%$ in every household which includes radio, television, cable phone, cellular phone, computer and internet [1].
Java Island is the most populous island in Indonesia where almost half the population of Indonesia is on the island [2]. The large number of residents caused ICT widely used in Java. According to Kemenkominfo, in 2014 the largest use of ICT is found in Java Island with percentage of $98.8 \%$. Almost every province in Java Island has access to ICT, one of them is West Java [1].

The latest data in 2010, West Java is one of the provinces that have the largest population in Java as shown in Table. 1 [3]. West Java residents certainly have a big hand in accessing and applying ICT, because the center of accessing technology and information is on the island of Java with the largest population in the province of West Java.

West Java is one of the provinces whose inhabitants work as farmers. Approximately 
$11,601,395$ people are livelihood as farmers, including agriculture sector and sub sector [4]. Total agricultural land in West Java reaches $60.57 \%$ of the total land area consisting of rice fields, plantations, and mixed plantations. West Java has great potential to develop agriculture into the leading sector [5].

In general, farmers have not been able to utilize ICT properly. An example of information and communication technology is internet. Internet can be easily accessed using ICT tools such as computers, mobile phones, and so on. However, professions in agriculture such as laborers, fishermen, traders, and artisans are classified as the lowest internet users of $6.7 \%$ [1]. The government has provided ICT facilities that can support the activities of West Java society today, especially the agricultural sector as a potential seed. Forms of information and communication technologies that already exist and can be used in the agricultural sector, such as Website Diperta Jabar, Cyber Extension, Jabar Cyber Province, and so on [6]. (Suhendar, 2011).

ICT used to facilitate in accessing information and communication. Through the utilization of ICT, farmers more easily increase productivity and reduce costs in running activities [7]. Farmers more easily obtain the supply of agricultural materials such as seeds, fertilizers, also easy to market and sell products, get information about technology, and store digital data. Communication technology facilitates farmers in communicating between farmers and consumers, even with the government. Farmers can receive useful inputs of knowledge and insights from other regions / regions easily and quickly.

Jatinangor sub-district is located in Sumedang District, West Java Province which has the highest economic growth. In this subdistrict, the agricultural sector is in the third position in contributing economically [8]. Agricultural activities become a mainstay and agricultural commodities serve as superior products. In this sub-district there are 7 agricultural commodities namely rice, corn, peanuts, cassava, sweet potatoes, chili, and red beans [9].

Economic growth in Jatinangor may be caused by incoming migrants. The large number of outsiders coming indicates that ICT users have entered the area. In contrast, farmers have not followed the development of the living environment and have not been involved in the use of information technology. On the other hand, it is found that agricultural output decreases every year. For example, corn production in 2009 in Jatinangor reached 15,050 quintals / year, while in 2011 it was 1,562 quintals / year, as well as others [3], [4], [10]. Lately the use of ICT has been growing in Jatinangor, but the product of agricultural activities actually decreased. Whereas if the farmers utilize ICT then it is believed that the productivity of agricultural activities can increase.

In this case, the use of ICT by farmers was still not optimal yet. ICT can improve agricultural productivity and minimize costs. However, farmer productivity is inversely proportional to the development of Jatinangor area. It was not yet known how far farmers use ICT. So it was necessary to know the level of ICT usage by farmers. Therefore, it is necessary to conduct an in-depth study that measures the level of ICT use by farmers in an effort to increase productivity.

Research on the measurement of the use of ICT is expected to be a reference for farmers as an evaluation of the application of ICT in support of agricultural activities. Measurement results can also be a benchmark of the information side in rural and agricultural development in Jatinangor

\section{METHODOLOGY}

According to the method of disclosure of results, this research is classified using descriptive method because it was designed to explain the situation based on the data obtained to solve the problem. The problem was knowing the ICT usage level indicator is expressed in the index number. The index number was obtained by formulating the operational definition of variables that can be used as parameters in knowing the level of ICT used of farmer groups in Jatinangor. Data processing in this research was done in quantitative method. Data obtained in the study were processed and analyzed with the SPSS 16.0 statistical tool and Microsoft Excel. Data analysis includes a few steps, namely: 
a) Recording, the data obtained are then recorded with MS. Excel and converted into scoring values from some qualitative data into quantitative data. The data is processed to determine the index value of the level of use of ICT.

b) Classification, the data that have been collected are classified or grouped based on the variables and parameters derived from the process of data retrieval research.

c) Validation, the data collected tested the validity of using SPSS for data obtained and processed is valid as the criteria in the study.

d) Verification, the data has been obtained and then summarized based on the problems and research results.

Variables were arranged based on operational definitions of variables derived from literature studies. It aims to obtain variables that could reflect the level of use of the level of use of ICT. In this case there were 50 variables to know the level of ICT used by farmers. Those variables were used in formulating the level of ICT used by farmers in Jatinangor. Indicators of the level of used of ICT had relevance in knowing the extent to which ICT technology could be applied by farmers in the field. The linkage of variables could be used as an indicator of the level of use of ICT in West Java Province. The indicator in question was focused on:

1. Farmer's Characteristic or FC

2. Farmers Environment or FE

3. ICT Characteristics or ICTC

4. Farmer Behavior or FB

\subsection{Testing Data Validity and Reliability}

The quantitative value of each parameter of the research results was then tested for validity and reliability. Validity and reliability test was done to see the question in the questionnaire filled by the respondent was feasible or not. Validity test was conducted to determine the eligibility of the items in a list of questions in defining the variables. Validity test using the formula based on which Sujarweni and Endrayanto [12] were summarized as follows:

$$
r=\frac{n \Sigma X Y-(\Sigma X)(\Sigma Y)}{\sqrt{\left[n \Sigma X^{2}-(X)^{2}\right]\left[n \Sigma Y^{2}-(\Sigma y)^{2}\right]}}
$$

where:

$$
\mathrm{r} \quad=\text { Correlation value to know the }
$$

$\mathrm{X}$ and $\mathrm{Y}=$ Variables tested

$\mathrm{n} \quad=$ Number of data

Then test the reliability to know the consistency of respondents in answering things related to the question. Reliability test coul be done simultaneously to all the questions. Test reliability could use the following formula:

$$
r=\left[\frac{k}{(k-1)}\right]\left[1-\frac{\Sigma{\sigma_{b}}^{2}}{\sigma_{t}{ }^{2}}\right]
$$

where:

$$
\begin{array}{ll}
\mathrm{r} & =\text { Reliability coefficient } \\
\mathrm{k} & =\text { amount of question } \\
\Sigma \sigma_{b}{ }^{2} & =\text { Total of variance } \\
\sigma_{t}{ }^{2} & =\text { Variance }
\end{array}
$$

\subsection{Preparation of ICT Level of Use Index}

After the data passed the validity test and reliability test then the data were analyzed using LQ (Location Quotient) analysis. The value of LQ is needed to determine the capability of an area over a wider scope of territory [11]. LQ analysis to know the ability of farmers group compare to the ability in sub-district Jatinangor. The LQ formula used was as follows:

where:

$$
L Q=\frac{\frac{X_{r}}{R V_{r}}}{\frac{X_{n}}{R V_{n}}} \text { or } \frac{X_{r} / X_{n}}{R V_{r} / R V_{n}}
$$

$$
\begin{aligned}
& X_{r}=\text { Value of parameters within the district y } \\
& X_{n}=\text { Value of parameters within Province } \\
& R V_{r}=\text { Value of total parameters within districts } \\
& R V_{n}=\text { Total value of parameters in Province }
\end{aligned}
$$

The formula was then used to determine the level of use of ICT of each farmer group in the District of Jatinangor was using the Usage Level Quotient (ULQ). Here is the ULQ formula:

where:

$$
U L Q=\frac{\frac{X_{r}}{R V_{r}}}{\frac{X_{n}}{R V_{n}}} \text { or } \frac{X_{r} / X_{n}}{R V_{r} / R V_{n}}
$$

$X_{r} \quad=$ Value of parameters in farmers group

$X_{n}=$ Value of parameters in the district

$R V_{r}=$ Total value of parameters in farmers group

$R V_{n}=$ The total value of parameters in the district 


\section{3. $\quad$ Merging ICT Rate Level Index}

Merging the index of the level of use of ICT was done to get the index value of the level of ICT usage in total from each parameter and indicator. The merger was done to get the ICTULQ Index (ICT Usage Level Quotient). One way to get ICTULQ index value was equation based on index calculation [13] that was using arithmetic mean of each indicator variable level of ICT used of farmer group in Jatinangor Subdistrict. The equations in question were as follows:

ICTULQ $=\Sigma\left(\frac{X_{r} / X_{n}}{R V_{r} / R V_{n}}\right) / j$

where:

$X_{r}=\quad$ Value of parameters in farmers group

$X_{n}=$ Value of parameters in the district of Jatinangor

$R V_{r}=\quad$ Total value of parameters in farmers group

$R V_{n}=\quad$ The total value of parameters in the district of Jatinangor

$j=$ The numbers of parameters

\section{RESULT AND DISCUSSION}

\subsection{Results of Variable Measurements and Indicators of ICT Use Level}

\section{a. Farmer Characteristics (FC)}

The ULQ index value of farmer's characteristics in utilizing the highest ICT was Harapan Farmer Group I in Cileles Village with value 1.263. Farmer Group with the second highest index value is Cileles Jaya Farmer Group located in Cileles Village with value 1.243. The farmer group was superior to other farmer groups in utilizing ICT based on the characteristics of the farmers they had. ULQ index value of the lowest characteristics of farmers is Mukti Sari Farmer Group located in Jatimukti Village with a value of 0.810 . Farmer group with the second lowest index value was Cilayung Sari I Farmer Group located in Cilayung Village with value 0,824 . Farmer groups are based on the characteristics of farmers were low in utilizing ICT.

Farmer groups having ULQ index value of farmers' characteristics in using ICT more than 1 (ULQ> 1) in which farmer groups are superior based on characteristics compared

to other farmer groups. There was also a farmer group that had a ULQ index score less than 1 (ULQ <1) where the farmer group has low farmer characteristics in utilizing ICTs compared to other groups. There are 20 farmer groups that have value of ULQ index of farmer characteristic with value more than 1 of them Cilayung Sari II $(1,218)$; Cilayung Sari III (1,100); Cilayung Sari V (1,156); Mekar Harapan (1,069); Cileles Jaya $(1,243)$; Harapan I (1,263); Mekar Bakti (1,024); Sukamaju (1,060); Sukanegla (1,029); Mekar Manah (1.021); Sugih Mukti (1,046); Ciawi Gajah (1,172); Tunas Harapan (1,095); Sawargi (1,186); Mulya Makmur (1,048); Bahagia II $(1,141)$; Bahagia III $(1,193)$; Jagawana (1.058); Tani Mukti I (1.012); and Sangkan Hurip $(1,059)$. While there are 27 groups of farmers who had value index ULQ characteristics of farmers in utilizing ICT less than 1.

Table 1. ULQ Index of Farmer's Characteristics (FC) in Utilizing ICT

\begin{tabular}{|c|c|c|}
\hline No & Farmers Group & Index ULQ FC \\
\hline (1) & (2) & (3) \\
\hline 1 & Cilayung Sari I & 0.824 \\
\hline 2 & Cilayung Sari II & 1.218 \\
\hline 3 & Cilayung Sari III & 1.100 \\
\hline 4 & Cilayung Sari IV & 0.920 \\
\hline 5 & Cilayung Sari V & 1.156 \\
\hline 6 & Mekar Harapan & 1.069 \\
\hline 7 & Cileles Jaya & 1.243 \\
\hline 8 & Harapan I & 1.263 \\
\hline 9 & Harapan III & 0.875 \\
\hline 10 & Sinar Mutiara & 0.958 \\
\hline 11 & Hikmat & 0.901 \\
\hline 12 & Al Hikmah & 0.904 \\
\hline 13 & Mekar Bakti & 1.024 \\
\hline 14 & Sukamaju & 1.060 \\
\hline 15 & Sukanegla & 1.029 \\
\hline 16 & Muara Harapan I & 0.906 \\
\hline 17 & Muara Harapan II & 0.965 \\
\hline 18 & Babakan Bandung & 0.942 \\
\hline 19 & Hegarmukti & 0.918 \\
\hline 20 & Mekar Manah & 1.021 \\
\hline 21 & Sukasari & 0.899 \\
\hline 22 & Sugih Mukti & 1.046 \\
\hline 23 & Caringin & 0.864 \\
\hline 24 & Ciawi Gajah & 1.172 \\
\hline 25 & Lumbung Sari & 0.956 \\
\hline 26 & Kiara Jaya & 0.996 \\
\hline 27 & Tunas Harapan & 1.095 \\
\hline 28 & Jeruk Mipis & 0.923 \\
\hline 29 & Sawargi & 1.186 \\
\hline
\end{tabular}




\begin{tabular}{llc}
\hline No & \multicolumn{1}{c}{ Farmers Group } & Index ULQ FC \\
\hline$(1)$ & \multicolumn{1}{c}{$(2)$} & $(3)$ \\
\hline 30 & Mulya Makmur & 1.048 \\
31 & Bahagia I & 0.968 \\
32 & Bahagia II & 1.141 \\
33 & Bahagia III & 1.193 \\
34 & Tunas Mekar & 0.941 \\
35 & Mekar Mukti & 0.994 \\
36 & Mukti Sari & 0.810 \\
37 & Sampurna & 0.876 \\
38 & Jagawana & 1.058 \\
39 & Tani Mukti I & 1.012 \\
40 & Tani Mukti II & 0.936 \\
41 & Citanggulun & 0.914 \\
42 & Sangkan Hurip & 1.059 \\
43 & Mekar Tani I & 0.872 \\
44 & Mekar Tani II & 0.856 \\
45 & Mekar Tani III & 0.964 \\
46 & Mekar Tani IV & 0.950 \\
47 & Bina Karya & 0.947 \\
\hline
\end{tabular}

\section{b. Farmers' Environment (FE)}

The value of the farmer's environmental ULQ index in supporting the highest ICT was the environment in the Caringin Farmer Group located in Desa Sayang with a value of 1.629. Environmental group of farmers with the second highest index value (1.423) was the Mekar Mukti Farmer Group neighborhood in Mekargalih Village. The farmer group's environment was superior to other farmer group environments in support of ICT utilization, thus supporting farmers in accessing ICT. The smallest environmental score of ULQ is the environment in Cilayung Sari I Farmer Group located in Cilayung Village with a value of 0.663 . Environmental group of farmers with the second lowest index value was the Cileles Jaya Farmer Group neighborhood located in Cileles Village with a value of 0.667 . Farmer groups were based on farmers' neighborhoods are low in utilizing ICT, because the farmer's environment was not very supportive than other farmer groups. The location of villages with farmer groups with low index values tend to be in upland areas, such as Cilayung village and Cileles village. This condition is inversely proportional to villages with high index values, such as Sayang village and Mekargalih Village. Both villages with high index values tend to be in the lowlands rather than Cilayung and Cileles villages, so the environment supports ICTs that were easily accessible to farmer groups. In addition,

Sayang and Mekargalih Village are located near the administrative center of Jatinangor sub-district close to the center of the crowd. The farmers in the village considered the farmers' groups to be easily accessible to ICT facilities. Farmer groups that had a farmer's ULQ index value in support of ICTs of more than 1 (ULQ> 1) in which the farmer group environment is superior to their environment compared to other farmer groups. There is also a farmer group that has a ULQ index score less than 1 (ULQ $<1$ ) where the farmer's environment in supporting ICT is very low compared to other groups. There were 23 farmers group that have value of environment ULQ index of farmers greater than 1 of them Harapan I (1.025); Harapan III (1.021); Al Hikmah (1.129); Sukanegla (1.201); Muara Harapan II (1.031); Babakan Bandung (1.042); Sukasari (1.406); Sugih Mukti (1.283); Caringin (1.629); Ciawi Elephant (1.418); Kiara Jaya (1.127); Tunas Harapan (1.229); Bahagia II (1.119); Harapan III (1.076); Tunas Mekar (1.031); Mekar Mukti (1.423); Mukti Sari (1.064); Sampurna (1.195); Jagawana (1.099); Tani Mukti I (1.075); Citanggulun (1.028); Mekar Tani I (1.187); and Bina Karya (1.091). Whereas there were 24 farmers group that get value of environment ULQ index of farmer less than 1.

Table 2. Environmental Farmer's ULQ Index (EF) in Support of ICT

\begin{tabular}{clc}
\hline No & \multicolumn{1}{c}{ Farmers Group } & Index ULQ EF \\
\hline$(1)$ & \multicolumn{1}{c}{$(2)$} & $(3)$ \\
\hline 1 & Cilayung Sari I & 0.663 \\
2 & Cilayung Sari II & 0.964 \\
3 & Cilayung Sari III & 0.913 \\
4 & Cilayung Sari IV & 0.912 \\
5 & Cilayung Sari V & 0.913 \\
6 & Mekar Harapan & 0.859 \\
7 & Cileles Jaya & 0.667 \\
8 & Harapan I & 1.025 \\
9 & Harapan III & 1.021 \\
10 & Sinar Mutiara & 0.895 \\
11 & Hikmat & 0.792 \\
12 & Al Hikmah & 1.129 \\
13 & Mekar Bakti & 0.945 \\
14 & Sukamaju & 0.901 \\
15 & Sukanegla & 1.201 \\
16 & Muara Harapan I & 0.945 \\
17 & Muara Harapan II & 1.031 \\
18 & Babakan Bandung & 1.042 \\
19 & Hegarmukti & 0.972 \\
20 & Mekar Manah & 0.920 \\
21 & Sukasari & 1.406 \\
\hline
\end{tabular}




\begin{tabular}{llc}
\hline No & \multicolumn{1}{c}{ Farmers Group } & Index ULQ EF \\
\hline$(1)$ & \multicolumn{1}{c}{$(2)$} & 1.283 \\
\hline 22 & Sugih Mukti & 1.629 \\
23 & Caringin & 1.418 \\
24 & Ciawi Gajah & 0.721 \\
25 & Lumbung Sari & 1.127 \\
26 & Kiara Jaya & 1.229 \\
27 & Tunas Harapan & 0.715 \\
28 & Jeruk Mipis & 0.992 \\
29 & Sawargi & 0.901 \\
30 & Mulya Makmur & 0.834 \\
31 & Bahagia I & 1.119 \\
32 & Bahagia II & 1.076 \\
33 & Bahagia III & 1.031 \\
34 & Tunas Mekar & 1.423 \\
35 & Mekar Mukti & 1.064 \\
36 & Mukti Sari & 1.195 \\
37 & Sampurna & 1.099 \\
38 & Jagawana & 1.075 \\
39 & Tani Mukti I & 0.685 \\
40 & Tani Mukti II & 1.028 \\
41 & Citanggulun & 0.706 \\
42 & Sangkan Hurip & 1.187 \\
43 & Mekar Tani I & 0.759 \\
44 & Mekar Tani II & 0.997 \\
45 & Mekar Tani III & 0.823 \\
46 & Mekar Tani IV & 1.031 \\
47 & Bina Karya &
\end{tabular}

\section{c. ICT Characteristics (ICTC)}

The ULQ index value of ICT characteristics utilized by the highest farmers was Mekar Harapan Farmer Group located in Cileles Village with a value of 1.193. Farmer group with the second highest index value was the Mulya Makmur Farmers Group neighborhood located in Cipacing Village with a value of 1.423. The farmer group was superior to other farmer group environments in the suitability of ICT characteristics, so that farmers could utilize appropriate ICTs based on their characteristics. The ULQ index value of the lowest ICT characteristics was Tunas Harapan Farmer Group located in Cipacing Village with a value of 0.837 . Farmers group with the second lowest index value was the environment of Farmers Group Jerup Mipis located in Cipacing Village with a value of 0.840 . The farmer group is based on the utilization of ICT according to its characteristics was low, because the characteristics of ICT was not very supportive compared to other farmers group. The location of the villages with farmers group with low index values were both located in Cipacing Village, but the second highest index was in the same village. This showed an imbalance regarding the views on ICT for farmers group in Cipacing Village. The farmers in the village differ on the presence of ICT in their neighborhood. Farmers group that have ULQ index value of ICT characteristics of more than 1 (ULQ> 1) where farmer groups consider ICT characteristics as needed compared to other farmer groups. There was also a farmers group that has an ULQ index score less than 1 (ULQ <1) where ICT characteristics are considered to be inconsistent with the needs. There were 20 farmers group that had ULQ index value of ICT characteristics greater than 1 of them Cilayung Sari I (1.049); Cilayung Sari II (1.030); Cilayung Sari III (1.068); Mekar Harapan (1.193); Cileles Jaya (1.160); Harapan I (1.042); Al Hikmah (1.011); Sukamaju (1.101); Kiara Jaya (1.027); Sawargi (1.085); Mulya Makmur (1.175); Mukti Sari (1.049); Sampurna (1.172); Jagawana (1.036); Tani Mukti I (1.014); Tani Mukti II (1.099); Citanggulun (1.125); Mekar Tani III (1.019); Mekar Tani IV (1.094); and Bina Karya (1.081). While there are 27 farmers group who had ULQ index value of ICT characteristics less than 1.

Table 3. ULQ Index of ICT Characteristics (ICTC)

\begin{tabular}{clc}
\hline \multicolumn{2}{c}{$($ ICTC } \\
\hline No & \multicolumn{1}{c}{ Farmers Group } & Index ULQ ICTC \\
\hline$(1)$ & \multicolumn{1}{c}{$(2)$} & 1.049 \\
\hline 1 & Cilayung Sari I & 1.030 \\
2 & Cilayung Sari II & 1.068 \\
3 & Cilayung Sari III & 0.973 \\
4 & Cilayung Sari IV & 0.976 \\
5 & Cilayung Sari V & 1.193 \\
6 & Mekar Harapan & 1.160 \\
7 & Cileles Jaya & 1.042 \\
8 & Harapan I & 0.972 \\
9 & Harapan III & 0.991 \\
10 & Sinar Mutiara & 0.878 \\
11 & Hikmat & 1.011 \\
12 & Al Hikmah & 0.900 \\
13 & Mekar Bakti & 1.101 \\
14 & Sukamaju & 0.949 \\
15 & Sukanegla & 0.940 \\
16 & Muara Harapan I & 0.958 \\
17 & Muara Harapan II & 0.957 \\
18 & Babakan Bandung & 0.902 \\
19 & Hegarmukti & 0.876 \\
20 & Mekar Manah & 0.956 \\
21 & Sukasari & 0.859 \\
22 & Sugih Mukti & 0.991 \\
23 & Caringin &
\end{tabular}




\begin{tabular}{clc}
\hline No & Farmers Group & Index ULQ ICTC \\
\hline$(1)$ & \multicolumn{1}{c}{$(2)$} & $(3)$ \\
\hline 24 & Ciawi Gajah & 0.984 \\
25 & Lumbung Sari & 0.959 \\
26 & Kiara Jaya & 1.027 \\
27 & Tunas Harapan & 0.837 \\
28 & Jeruk Mipis & 0.840 \\
29 & Sawargi & 1.085 \\
30 & Mulya Makmur & 1.175 \\
31 & Bahagia I & 0.954 \\
32 & Bahagia II & 0.963 \\
33 & Bahagia III & 0.908 \\
34 & Tunas Mekar & 0.913 \\
35 & Mekar Mukti & 0.987 \\
36 & Mukti Sari & 1.049 \\
37 & Sampurna & 1.172 \\
38 & Jagawana & 1.036 \\
39 & Tani Mukti I & 1.014 \\
40 & Tani Mukti II & 1.099 \\
41 & Citanggulun & 1.125 \\
42 & Sangkan Hurip & 0.892 \\
43 & Mekar Tani I & 0.918 \\
44 & Mekar Tani II & 0.901 \\
45 & Mekar Tani III & 1.019 \\
46 & Mekar Tani IV & 1.094 \\
47 & Bina Karya & 1.081 \\
\hline
\end{tabular}

\section{d. Farmer Behavior (FB)}

The highest value of ULQ index of farmer's behavior toward ICT was Mekar Tani II Farmer Group located in Jatiroke Village with value 1.189. Environmental group of farmers with the second highest index value was the environment Sugih Mukti Farmer Group in Sayang village with a value of 1.175. The farmers group was superior to other farmers group in terms of behavior in utilizing ICT. so the farmer had positive attitude with the presence of ICT. ULQ index value of the lowest farmer behavior was Sampurna Farmers Group located in Jatimukti Village with value 0.761. Farmer group with the second lowest index value was the Citanggulun Farmers Group neighborhood located in Cintamulya Village with a value of 0.813 . The farmers group were based on their behavior in making use of ICTs relatively low compared to other farmer groups. Farmers group having ULQ value of farmer behavior more than 1 (ULQ> 1) where farmers behavior toward ICT was very positive compared to other farmers group. There was also a farmers group with a ULQ index score less than 1 (ULQ <1) where the behavior of farmers towards ICT was quite low. There were 22 farmers group that had value of ULQ index of farmer behavior more than 1 of them Cilayung Sari I (1.152); Cilayung Sari II (1.008); Cilayung Sari IV (1.015); Cilayung Sari V (1.064); Mekar Harapan (1.050); Harapan I (1.170); Bahagia III (1.015); Hikmat (1.062); Hegarmukti (1.026); Sugih Mukti (1.175); Kiara Jaya (1.019); Jeruk Mipis (1.083); Sawargi (1.020); Bahagia II (1.050); Tunas Mekar (1.035); Mekar Mukti (1.028); Mukti Sari (1.029); Sangkan Hurip (1.081); Mekar Tani I (1.089); Mekar Tani II (1.189); Mekar Tani III (1.047); and Mekar Tani IV (1.084). While there are 25 farmers group that had ULQ index value of ICT behavior less than 1 .

Table 4. ULQ Index of Farmers Behavior (FB) on ICT

\begin{tabular}{|c|c|c|}
\hline No & Farmers Group & Index ULQ PP \\
\hline (1) & (2) & (3) \\
\hline 1 & Cilayung Sari I & 1.152 \\
\hline 2 & Cilayung Sari II & 1.008 \\
\hline 3 & Cilayung Sari III & 0.992 \\
\hline 4 & Cilayung Sari IV & 1.015 \\
\hline 5 & Cilayung Sari V & 1.064 \\
\hline 6 & Mekar Harapan & 1.050 \\
\hline 7 & Cileles Jaya & 0.975 \\
\hline 8 & Harapan I & 1.170 \\
\hline 9 & Harapan III & 1.015 \\
\hline 10 & Sinar Mutiara & 0.939 \\
\hline 11 & Hikmat & 1.062 \\
\hline 12 & Al Hikmah & 0.866 \\
\hline 13 & Mekar Bakti & 0.967 \\
\hline 14 & Sukamaju & 0.908 \\
\hline 15 & Sukanegla & 0.981 \\
\hline 16 & Muara Harapan I & 0.967 \\
\hline 17 & Muara Harapan II & 0.901 \\
\hline 18 & Babakan Bandung & 0.995 \\
\hline 19 & Hegarmukti & 1.026 \\
\hline 20 & Mekar Manah & 0.962 \\
\hline 21 & Sukasari & 0.903 \\
\hline 22 & Sugih Mukti & 1.175 \\
\hline 23 & Caringin & 0.885 \\
\hline 24 & Ciawi Gajah & 0.928 \\
\hline 25 & Lumbung Sari & 0.986 \\
\hline 26 & Kiara Jaya & 1.019 \\
\hline 27 & Tunas Harapan & 0.945 \\
\hline 28 & Jeruk Mipis & 1.083 \\
\hline 29 & Sawargi & 1.020 \\
\hline 30 & Mulya Makmur & 0.849 \\
\hline 31 & Bahagia I & 0.998 \\
\hline 32 & Bahagia II & 1.050 \\
\hline 33 & Bahagia III & 0.861 \\
\hline 34 & Tunas Mekar & 1.035 \\
\hline 35 & Mekar Mukti & 1.028 \\
\hline 36 & Mukti Sari & 1.029 \\
\hline 37 & Sampurna & 0.761 \\
\hline
\end{tabular}


Karisnoviandi, et al./JIITA Vol.1 Issue 2 (2017) 8-17

\begin{tabular}{clc}
\hline No & \multicolumn{1}{c}{ Farmers Group } & Index ULQ PP \\
\hline$(1)$ & \multicolumn{1}{c}{$(2)$} & $(3)$ \\
\hline 38 & Jagawana & 0.945 \\
39 & Tani Mukti I & 0.943 \\
40 & Tani Mukti II & 0.951 \\
41 & Citanggulun & 0.813 \\
42 & Sangkan Hurip & 1.081 \\
43 & Mekar Tani I & 1.089 \\
44 & Mekar Tani II & 1.189 \\
45 & Mekar Tani III & 1.047 \\
46 & Mekar Tani IV & 1.084 \\
47 & Bina Karya & 0.937 \\
\hline
\end{tabular}

\section{e. Measurement Result of ICT Rate of Use of Farmer Groups}

Result of analysis of ICT Level Usage Level Quotient (ICTULQ) level of ICT utilization of farmer group in Jatinangor Subdistrict has varied value. There is a farmer group that has more than 1 ICTULQ index (ICTULQ> 1) where the farmer group is responsive to ICT compared to other farmer groups. There is also a farmer group with less than 1 ICT ULQ index (ICTULQ $<1$ ) where the farmer group has not been responsive to ICT use over other groups.

There are 19 farmer groups that have ICTULQ Index value greater than 1 of them Harapan I (1.1380); Cileles Jaya (1.1110); Tunas Harapan (1.1014); Sawargi (1.0943); Cilayung Sari II (1.0770); Ciawi Gajah (1.0529); Cilayung Sari III (1.0500); Cilayung Sari V (1.0474); Bahagia II (1.0467); Mulya Makmur (1.0423); Mekar Tani IV (1.0320); Sukamaju (1.0302); Mekar Mukti (1.0249); Jagawana (1.0245); Kiara Jaya (1.0217); Sugih Mukti (1.0166); Mekar Tani III (1.0077); Bina Karya (1.0034) and Tani Mukti I (1.0001). While there are 28 farmer groups with ICTULQ Index score less than 1 . Table 5 shows the index of farmer group ICT usage rates derived from farmer characteristics, farmer's environment, ICT characteristics, and farmer behavior in Jatinangor subdistrict, Sumedang district.

Farmer groups that have the highest ICTULQ Index value were Harapan I Farmer Group located in Farmers group union (Gapoktan) Bina Karya Mandiri Cileles village with an index value of ICT usage rate of 1.1380 .

Table 5. ICT Rate Use Index of Farmers Group in Jatinangor Sub-district

\begin{tabular}{|c|c|c|c|}
\hline No & Farmers Group & $\begin{array}{c}\text { Index } \\
\text { ICTULQ }\end{array}$ & Rank \\
\hline \multicolumn{4}{|c|}{$(\mathrm{X} 1-\mathrm{X} 50)$} \\
\hline (1) & (2) & (3) & $(4)$ \\
\hline 1 & Cilayung Sari I & 0.9828 & 24 \\
\hline 2 & Cilayung Sari II & 1.0770 & 5 \\
\hline 3 & Cilayung Sari III & 1.0500 & 7 \\
\hline 4 & Cilayung Sari IV & 0.9634 & 31 \\
\hline 5 & Cilayung Sari V & 1.0474 & 8 \\
\hline 6 & Mekar Harapan & 1.1014 & 3 \\
\hline 7 & Cileles Jaya & 1.1110 & 2 \\
\hline 8 & Harapan I & 1.1380 & 1 \\
\hline 9 & Harapan III & 0.9561 & 37 \\
\hline 10 & Sinar Mutiara & 0.9628 & 32 \\
\hline 11 & Hikmat & 0.9239 & 46 \\
\hline 12 & Al Hikmah & 0.9514 & 39 \\
\hline 13 & Mekar Bakti & 0.9561 & 36 \\
\hline 14 & Sukamaju & 1.0302 & 12 \\
\hline 15 & Sukanegla & 0.9959 & 20 \\
\hline 16 & Muara Harapan I & 0.9366 & 45 \\
\hline 17 & Muara Harapan II & 0.9510 & 40 \\
\hline 18 & Babakan Bandung & 0.9668 & 28 \\
\hline 19 & Hegarmukti & 0.9409 & 44 \\
\hline 20 & Mekar Manah & 0.9428 & 43 \\
\hline 21 & Sukasari & 0.9533 & 38 \\
\hline 22 & Sugih Mukti & 1.0166 & 16 \\
\hline 23 & Caringin & 0.9658 & 29 \\
\hline 24 & Ciawi Gajah & 1.0529 & 6 \\
\hline 25 & Lumbung Sari & 0.9504 & 41 \\
\hline 26 & Kiara Jaya & 1.0217 & 15 \\
\hline 27 & Tunas Harapan & 0.9638 & 30 \\
\hline 28 & Jeruk Mipis & 0.9156 & 47 \\
\hline 29 & Sawargi & 1.0943 & 4 \\
\hline 30 & Mulya Makmur & 1.0423 & 10 \\
\hline 31 & Bahagia I & 0.9616 & 33 \\
\hline 32 & Bahagia II & 1.0467 & 9 \\
\hline 33 & Bahagia III & 0.9925 & 21 \\
\hline 34 & Tunas Mekar & 0.9575 & 35 \\
\hline 35 & Mekar Mukti & 1.0249 & 13 \\
\hline 36 & Mukti Sari & 0.9732 & 27 \\
\hline 37 & Sampurna & 0.9862 & 23 \\
\hline 38 & Jagawana & 1.0245 & 14 \\
\hline 39 & Tani Mukti I & 1.0001 & 19 \\
\hline 40 & Tani Mukti II & 0.9897 & 22 \\
\hline 41 & Citanggulun & 0.9808 & 25 \\
\hline 42 & Sangkan Hurip & 0.9764 & 26 \\
\hline 43 & Mekar Tani I & 0.9613 & 34 \\
\hline 44 & Mekar Tani II & 0.9482 & 42 \\
\hline 45 & Mekar Tani III & 1.0077 & 17 \\
\hline 46 & Mekar Tani IV & 1.0320 & 11 \\
\hline 47 & Bina Karya & 1.0034 & 18 \\
\hline
\end{tabular}

This could not be separated from the contribution of the indicator of the use of ICT so that the Harapan Farmer Group I become the peasant group with the highest index value. In addition, the farmer group that had the lowest index ICTULQ index that was 
Poktan Jeruk Mipis located in Gapoktan Mulya Jaya Village Cipacing with the index value of the use of ICT level of 0.9156 . Just as before, that value was not separated from the contribution of indicators of the use of ICT in Jatinangor.

Table 6. Percentage of ICT Absorption Rate Based on the ULQ Index

\begin{tabular}{lllll}
\hline No. & $\begin{array}{l}\text { Farmers } \\
\text { Group }\end{array}$ & $\begin{array}{l}\text { Index } \\
\text { ICTULQ }\end{array}$ & $\begin{array}{l}\text { Index } \\
\text { Status }\end{array}$ & $\begin{array}{l}\text { Percent } \\
\text { Value } \\
\text { Index }\end{array}$ \\
\hline 1 & Harapan I & 1.1380 & Highest 1 & $50 \%$ \\
\hline 2 & $\begin{array}{l}\text { Cileles } \\
\text { Jaya }\end{array}$ & 1.1110 & Highest 2 & $42 \%$ \\
\hline 3 & Sukanegla & 0.9959 & Average & $50 \%$ \\
\hline 4 & $\begin{array}{l}\text { Babakan } \\
\text { Bandung }\end{array}$ & 0.9668 & Average & $40 \%$ \\
\hline 5 & Hikmat & 0.9239 & Lowest 2 & $30 \%$ \\
\hline 6 & $\begin{array}{l}\text { Jeruk } \\
\text { Mipis }\end{array}$ & 0.9156 & Lowest 1 & $36 \%$ \\
\hline
\end{tabular}

Farmer groups that have the highest ICTULQ index value are Poktan Harapan I with total value of ULQ index more than one amounting to 25 grains of total 50 index items. The percentage of ICT that can be absorbed by the Poktan Harapan I is 50\%. Poktan Harapan I despite being the most responsive farmer group to ICT, only able to absorb ICT by $50 \%$. It shows that ICT has not been able to be absorbed optimally by the farmer group with the highest ICTULQ index value though. The farmer group with the lowest ICTULQ index value is Poktan Jeruk Mipis with the total value of more than one ULQ index from 18 items out of a total of 50 index items. The percentage of ICT that could be absorbed by Poktan Mipis is 36\%. The farmer groups in Jatinangor sub-district as a whole could not be said to be able to absorb ICT optimally.

\section{CONCLUSION}

The conclusion of the research based on the problems and research objectives, are as follows:

1. Measurement of ICT utilization rate by farmer group in Jatinangor includes 4 indicators that are: farmer characteristics, farmer environment, ICT characteristics, and farmer behavior.

2. Farmer groups that have the highest level of use of ICT in 2016 in Jatinangor is Kelompok Tani Harapan I as a member of the Gapoktan Bina Karya Mandiri, Cileles
Village, with the index of 1.1380 and the absorption rate of ICT is about $50 \%$. While farmer group which have the lowest level of ICT utilization in Jatinangor is Kelmpok Tani Mipis as member of Gapoktan Mulya Jaya, Cipacing village with index 0,9156 and ICT absorption rate about $36 \%$.

Recommendation for future consideration are as follows:

1. Farmers group in Jatinangor need more guidance on introduction, briefing, and training in using ICT by extension workers of Agriculture UPTD of Jatinangor Subdistrict so further more the farmers could be more responsive to ICT.

2. It is better for Jatinangor sub-district to facilitate ICT facilities at village, so that farmers group will be interested in the presence of ICT and using/apply ICT properly.

\section{REFERENCES}

[1] Kementerian Komunikasi dan Informatika Republik Indonesia. 2014. Buku Saku Survey Indikator Akses dan Penggunaan TIK pada Rumah Tangga Tahun 2014. Puslitbang PPI-Kominfo. Jakarta

[2] Republika.co.id. 2014. Setengah Penduduk Indonesia Tinggal di Pulau Jawa. Accessed via URL: http://nasional.republika.co.id/berita/ nasional/umum/14/02/07/n0mec5setengah-penduduk-indonesia-tinggaldi-pulau-jawa. Accessed on 11/12/2015

[3] Badan Pusat Statistik. 2012. Penduduk Indonesia Menurut Provinsi 1971, 1980, 1990, 1995, 2000, dan 2010. Available at: http://www.bps.go.id/ linkTabelStatis/view/id/1267.

Accessed on 11/12/2015

[4] Badan Pusat Statistik. 2013. Sensus Pertanian 2013: Jumlah Petani Menurut Sektor/Subsektor dan Jenis Kelamin Tahun 2013 Provinsi Jawa Barat. Available at: http: // st2013.bps.go.id/dev/ st2013/ index. php $/$ site $/$ tabel?tid $=23 \&$ wid $=3200000$ 000 . Accessed on 23/12/2015 
[5] Harjowiryono, M. 2012. Tinjauan Ekonomi dan Keuangan Daerah. Provinsi Jawa Barat: Direktorat Jenderal Perimbangan Keuangan.

[6] Suhendar, E. 2011. Pemanfaatan Teknologi Informasi dalam Pembangunan Pertanian. Prosiding Seminar Nasional Informatika Pertanian Tahun 2011, page : 20 - 29. Bandung

[7] Food and Agriculture Organization of the United Nation. 2011. Challenges and Opportunities for Capturing Impact in ICT Initiative in Agriculture. Accessed via URL: www.fao.org/ docrep/017/ap853e/ap853e.pdf. Accessed on 04/12/2015

[8] Wulandari, P. 2014. Analisis Pertumbuhan Ekonomi dan Kesenjangan Distribusi Pendapatan di Kawasan Jatinangor. Pusat Kajian Pendidikan dan Pelatihan Aparatur I, Lembaga Administrasi Negara. Bandung

[9] Badan Pusat Statistik. 2011. Kecamatan Jatinangor dalam Angka Tahun 2011. Badan Pusat Statistik Provinsi Jawa Barat

[10] Badan Pusat Statistik. 2013. Kecamatan Jatinangor dalam Angka Tahun 2013. Badan Pusat Statistik Provinsi Jawa Barat.

[11] Rizal, F. 2016. Analisis Location Quetiont (LQ) Studi Kasus Lampung Tengah. Institut Teknologi Bandung. Bandung.

[12] Sujarweni, V. W. dan Endrayanto, P. 2012. Statistik untuk Penelitian. Graha Ilmu. Yogyakarta

[13] UNDP. 2014. Sustaining Human Progress Reducing Valnerabiliies and Buliding Resilience. Available at: www.id.undp.org. Acessed on 05/02/2017 